Vol.1 No.1 Januari 2018

ISSN 2614-2775

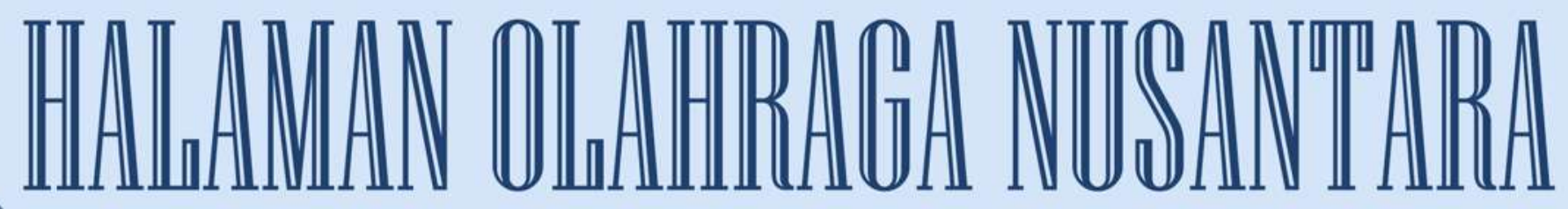

Curnal \&lmu Q Xeolahragaan

Diterbitkan Oleh:

Program Studi Pendidikan Olahraga

Pakultas Keguruan dan Ilmu Pendidikan

Universitas PGRI Palembang

\begin{tabular}{|c|c|c|c|c|c|}
\hline Jurnal & Volume & Nomor & Halaman & Palembang & ISSN \\
\hline IItaman Oahraya Vissantara & 1 & 1 & $1 \cdot 132$ & 2018 & 2014.27175 \\
\hline
\end{tabular}


Artikel Ilmiah

Perbedaan Variasi Latihan Juggling dan Rasio Koordinasi Mata-Kaki terhadap Hasil Kontrol Bola dari Tendangan Jarak Jauh Sepak Bola Hengki Kumbara

Hubungan Antara Kekuatan Otot Tungkai dan Kekuatan Otot Lengan terhadap Hasil Kecepatan Renang 50 Meter Gaya Bebas pada Atlet Putri Club Bangka Swimming

Farizal Imansyah

Motivasi Mahasiswa PGSD dalam Olahraga Rekreasi di Water Fun Kota Palembang

M. TaheriAkikbar

Pengaruh Metode Sirkuit terhadap Kemampuan Teknik Dasar Sepakbola pada Kegiatan Ekstrakurikuler Siswa SMAN 5 Kabupaten Tebo Alek Oktadinata

Kontribusi. Daya Ledak Otot Thung:kai dan Kelentukan dengan [1asil] Lompat Tinggi Gaya Flop Mahasiswa Program Studi Pendidikan Olahraga Universitas PG:RIPalembang IIham Arvan Junaidi

Kemampuan Meng.gining Bola (IStudi Korelasional Kecepatan ( $\left.x_{1}\right)$ dan Kelineahan $\left(x_{2}\right)$ dengan Kemampuan Dribel pada Permainan Sepabola Siswa Sekolah Menengah Pertama) Putwi Cicilla Kristina

Revitalisasi Masyarakat ¿iban/Perkotaan Melalui Olahraga Petanque Arcdo okilanda

Peranan Mata Pelajaran Pendidikan Jasmani dalam Meningkatkan Kesadaran Kesehatan \$iswa đi Lingkungan \$ekolah Dasar

Negeri nur Tegalkalong Kabupaten sumedang

№ Siti nurfaeni Sofa dan Anggi Setia Lengkana

Peran Motor Educability di dalam Meningkatan Keterampilan Olahraga pada Pembelajaran Penjas

gieru Syarili Lesmana

MơtivasiAnggota Pusat Kebugaran dalam Mengikuti Latihan Fitness padaKota Sekaycu Sugar Wanto

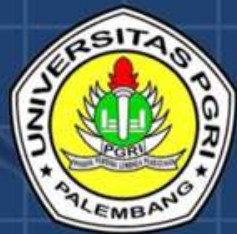

Program Studi Pendidikan Olahraga Fakultas Keguruan dan Ilmu Pendidikan Universitas PGRI Palembang 
ISSN 2614-2775

\section{HALAMAN OLAHRAGA NUSANTARA}

Jurnal Ilmu Keolahragaan

Volume 1, Nomor 1, Januari 2018

Pelindung/Penasehat

Dr. H. Bukman Lian, M. M., M. Si.

Penanggung Jawab

Dr. Dessy Wardiah, M. Pd.

Ketua Dewan Redaksi

Drs. M. Nirwan, M. Pd.

\section{Wakil Ketua Dewan Redaksi}

Ilham Arvan Junaidi, M. Pd.

\section{Sekretaris}

Nasrullah, M. Pd.

Penyunting Pelaksana

Rafel Orlando, M. Pd

Ardo Okilanda, M. Pd

\section{Penyunting Ahli/ Mitra Bestari}

Prof. Dr. A. Sofyan Hanif, M. Pd (Universitas Negeri Jakarta)

Dr. Ronni Yenes, M. Pd (Universitas Negeri Padang)

Dr. Putri Cicilia Kristina, M. Pd (Universitas PGRI Palembang)

\section{Tata Usaha}

M. Taheri Akbar, M. Pd

\section{Setting:}

Dede Dwiansyah Putra, M. Pd

Alamat Redaksi:

Prodi Pendidkan Olahraga Fakultas Keguruan Ilmu dan Pendidikan Universitas PGRI Palembang

Jl. Jendral A. Yani Lorong Gotong Royong 9/10 Ulu Palembang Telp. 0711-510043, Fax. 0711-514782

e-mail jurnal: rafelorlando333@gmail.com

e-mail : ardo.oku@ univpgri-palembang.ac.id

website: univpgri-palembang.ac.id 


\section{DAFTAR ISI}

Perbedaan Variasi Latihan Juggling dan Rasio Koordinasi Mata-Kaki terhadap Hasil Kontrol Bola dari Tendangan Jarak Jauh Sepak Bola

Hubungan Antara Kekuatan Otot Tungkai dan Kekuatan Otot Lengan terhadap Hasil Kecepatan Renang 50 Meter Gaya Bebas pada Atlet Putri Club Bangka Swimming

- Farizal Imansyah

Motivasi Mahasiswa PGSD dalam Olahraga Rekreasi di Water Fun Kota Palembang

- $\quad$ M. Taheri Akhbar

Pengaruh Metode Sirkuit terhadap Kemampuan Teknik Dasar Sepakbola pada Kegiatan Ekstrakurikuler Siswa SMAN 5 Kabupaten Tebo

- Alek Oktadinata

Kontribusi Daya Ledak Otot Tungkai dan Kelentukan dengan Hasil Lompat Tinggi Gaya Flop Mahasiswa Program Studi Pendidikan Olahraga Universitas PGRI Palembang

- Ilham Arvan Junaidi

Kemampuan Menggiring Bola (Studi Korelasional Kecepatan $\left(\mathrm{x}_{1}\right)$ dan Kelincahan $\left(\mathrm{x}_{2}\right)$ dengan Kemampuan Dribel pada Permainan Sepabola Siswa Sekolah Menengah Pertama)

- Putri Cicilia Kristina

Revitalisasi Masyarakat Urban/Perkotaan Melalui Olahraga Petanque

- $\quad$ Ardo okilanda

Peranan Mata Pelajaran Pendidikan Jasmani dalam Meningkatkan

Kesadaran Kesehatan Siswa di Lingkungan Sekolah Dasar

Negeri III Tegalkalong Kabupaten Sumedang

- $\quad$ N. Siti nur'aeni Sofa dan Anggi Setia Lengkana

Peran Motor Educability di dalam Meningkatan Keterampilan

Olahraga pada Pembelajaran Penjas

- Heru Syarli Lesmana 
Motivasi Anggota Pusat Kebugaran dalam Mengikuti Latihan Fitness pada Kota Sekayu

Sugar Wanto 


\title{
KONTRIBUSI DAYA LEDAK OTOT TUNGKAI DAN KELENTUKAN \\ DENGAN HASIL LOMPAT TINGGI GAYA FLOP MAHASISWA PROGRAM STUDI PENDIDIKAN OLAHRAGA UNIVERSITAS PGRI PALEMBANG
}

\author{
Oleh: Ilham Arvan Junaidi \\ (Dosen Universitas PGRI Palembang)
}

\begin{abstract}
Abstrak
Permasalahan yang terjadi adalah masih rendahnya hasil lompat tinggi gaya flop mahasiswa siswa program studi pendidikan olahraga yang diduga disebebkan oleh daya ledak otot tungkai dan kelentukan. Penelitian ini bertujuan untuk mengetahui kontribusi daya ledak otot tungkai dan kelentukan dengan hasil lompat tinggi gaya flop. Jenis Penelitian adalah korelasional, Populasi dalam penelitian ini adalah seluruh mahasiswa mata kuliah atletik 3 yang berjumlah 254 orang dengan teknik penarikan sampel purposive sampling, sehingga sampel berjumlah 37 orang siswa putra. Pengambilan data dilakukan dengan cara daya ledak otot tungkai dengan menggunakan tes vertical jump, kelentukan dengan tes kayang, dan lompat tinggi gaya flop dengan menggunakan tes lompat tinggi gaya flop. Analisis data dilakukan dengan menggunakan statistik regresi dan korelasi. Dari analisis data diperoleh hasil: (1) terdapat hubungan daya ledak otot tungkai dengan hasil lompat tinggi gaya flop mahasiswa program studi pendidikan olahraga dengan kontribusi sebesar 20,25\%; (2) terdapat hubungan kelentukan dengan hasil lompat tinggi gaya flop mahasiswa program studi pendidikan olahraga dengan kontribusi sebesar 11,56\%; dan (3) terdapat hubungan daya ledak otot tungkai dan kelentukan secara bersama-sama dengan hasil lompat tinggi gaya flop mahasiswa program studi pendidikan olahraga dengan kontribusi sebesar 26,01\%.
\end{abstract}

Kata Kunci: Daya Ledak Otot Tungkai, Kelentukan, Lompat Jauh Gaya Flop

\section{CONTRIBUTION OF EXPLOSIVE MUSCLE LIMB AND FLEXIBILITY WITH FLOP STYLE HIGH JUMP RESULTS COLLEGE STUDENT ON SPORTS EDUCATION PROGRAM PGRI PALEMBANG UNIVERSITY}

\begin{abstract}
Problems that occur are still low results high jump student flop college student sports education program allegedly caused by explosive muscle limb power and flexibility. This study aims to determine the contribution of explosive muscle limb power and flexibility with high jump style flop. Type of research is correlational, Population in this research is all student of athletic course 3 which amounted to 254 people with technique of sampling purposive sampling, so that sample amounted to 37 male college student. Data collection was performed by means of explosive muscle limbs by using vertical jump test, flexibilty with whell pose test, and high jump flop
\end{abstract}


style by using high jump flop style test. Data analysis was done by using regression and correlation statistic. From the analysis of data obtained the results: (1) There is correlation of muscle limb explosive power with high jump results flop student sports education program with a contribution of 20.25\%; (2) There is a correlation flexibility with high jump results of flop style of sports education program students with contribution of 11.56\%; and (3) There is correlation of muscle limb explosive power and flexibility with high jump result flop of student of sports education program with contribution equal to $26,01 \%$.

Keywords: Explosive Muscle Limb, Flexibility, High Jump Flop Style

\section{A. PENDAhuluan}

Olahraga telah menjadi sesuatu yang dianggap penting pada saat ini, karena dengan berolahraga akan meningkatkan kualitas manusia baik jasmani maupun rohani. Olahraga berperan penting dalam pembentukan karakter bangsa, sehingga pemerintah mendukung setiap pembinaan olahraga. Pembinaan olahraga bukan hanya pada olahraga prestasi semata, namun pemerintah juga menekankan pembinaan olahraga rekreasi, olahraga pendidikan, dan sebagainya. Hal ini dijelaskan Undang-Undang RI No. 3 Tahun 2005 tentang Sistem Keolahragaan Nasional pasal 27 ayat 1 menyatakan: "Pembinaan dan pengembangan olahraga prestasi dilaksanakan dan diarahkan untuk mencapai prestasi olahraga pada tingkat daerah, nasional, dan internasional”.

Salah satu perguruan tinggi di sumatera selatan yang juga ikut mengembangkan pembinaan olahraga pedidikan adalah Universitas PGRI Palembang melalui Program Studi Pendidikan Olahraga. Dengan program studi ini diharapkan mampu memberikan kontribusinya dalam menyediakan guru olahraga yang berkualitas dan mampu bersaing dalam dunia pendidikan. Dalam program studi pendidikan olahraga tersebut, mahasiswa diberikan materi tentang berbagai cabang olahraga, salah satunya adalah olahraga atletik.

Menurut Ballesteros (1993: 01), atletik adalah “aktifitas jasmani yang kompetitif, meliputi beberapa nomor lomba yang terpisah berdasarkan kemampuan gerak dasar manusia seperti berjalan, berlari, melompat, dan 
melempar." Atletik memiliki banyak nomor perlombaan, salah satu diantaranya adalah lompat tinggi. Syarifuddin (1998: 106) menyatakan bahwa "lompat tinggi merupakan suatu bentuk gerakan melompat keatas dengan cara mengangkat kaki ke depan atas dalam upaya membawa titik berat badan setinggi mungkin dan secepat mungkin jatuh (mendarat) yang dilakukan dengan cepat dan dengan jalan melakukan tolakan pada salah satu kaki untuk mencapai suatu ketinggian tertentu".

Dalam lompat tinggi terdapat bermacam-macam gaya atau cara melompat. Macam-macam gaya dalam lompat tinggi salah satunya yaitu gaya flop. Lompat tinggi gaya flop merupakan teknik yang paling banyak digunakan pada saat ini. Hal ini dapat dilihat pada setiap pertandingan, baik di tingkat lokal, nasional, regional maupun internasional.

Dari informasi yang didapatkan dari dosen atletik II program studi pendidikan olahraga, masih banyak mahasiswa yang belum dapat melakukan lompat tinggi secara maksimal dari lompatan yang dilakukan khususnya gaya flop banyak mengenai mistar pada saat melenting di udara sehingga akhirnnya menjatuhi mistar. Hal ini diduga disebabkan oleh power otot tungkai dan kelentukan.

Lompat tinggi adalah salah satu nomor atletik yang ikut diperlombakan sebagai olahraga prestasi, baik ditingkat lokal, nasional, regional maupun internasional. Bompa (2006: 9) menjelaskan bahwa komponen kognitif, motorik, afektif, dan emosional merupakan komponen-komponen yang selalu turut ambil bagian dalam mengkonstruksi perilaku motorik manusia dalam berolahraga.

Untuk mendapatkan hasil lompat tinggi yang baik, pelompat harus mampu menguasai teknik-teknik melompat dengan efektif dan efisien, memiliki kemampuan motorik yang baik, serta mengetahui faktor-faktor yang menentukan sekaligus mempengaruhi hasil lompatan. Faktor-faktor tersebut antara lain; daya ledak otot tungkai, merupakan faktor penting untuk kemampuan lompat tinggi gaya flop yang baik akan tercipta apabila mahasiswa memiliki daya ledak otot 
tungkai yang baik. Menurut Harsono (2006: 58), daya ledak merupakan kekuatan otot untuk mengerahkan kekuatan maksimal dalam waktu yang sangat cepat.

Faktor kelentukan juga berperan dalam pelaksanaan lompat tinggi gaya flop, karena kelentukan merupakan kemampuan seseorang untuk dapat melakukan gerak dengan ruang gerak seluas-luasnya dalam persendian. Pelaksanaan lompat tinggi gaya flop membutuhkan kelentukan pinggang. Kelentukan pinggang ini sangat dibutuhkan pada saat melakukan fase gerakan melayang di atas mistar, hal ini disebabkan karena kelentukan pinggang akan membantu pelompat mempermudah gerakan fase melayang di atas mistar.

Teknik-teknik dasar lompat tinggi berkaitan dengan penyelesaian fasefase lompatan mulai dari gerakan awalan, tolakan, melayang, sampai pada gerakan pendaratan. Teknik ini dapat diselesaikan dengan baik, jika ditunjang dengan kemampuan motorik yang baik, seperti kecepatan, kekuatan, daya ledak otot tungkai, koordinasi gerak, dan kelentukan.

Syarifuddin (1998: 9) mengemukakan beberapa persyaratan yang harus dipenuhi pelompat tinggi yang baik adalah: kecepatan ditambah kondisi (tenaga untuk melakukan lompatan, kemudahan dalam melakukan gerakan, koordinasi gerak), serta ditambah dengan teknik (ancang-ancang yang baik, tolakan, melayang dan pendaratan). Dalam pelaksanaannya berlangsung sangat cepat dan berkelanjutan. Dalam lompat tinggi gaya flop, pengambilan awalan dapat dilakukan dengan tiga macam pendekatan: (1) pendekatan kurva, (2) pendekatan “J”, dan (3) pendekatan hook (Bowerman dalam Winarno, 2006: 77).

Harsono (2006: 58) menyatakan bahwa daya ledak adalah kekuatan otot untuk mengerahkan kekuatan maksimal dalam waktu yang sangat cepat. Daya ledak merupakan salah satu komponen biomotorik yang penting dalam kegiatan olahraga, karena daya ledak akan menentukan seberapa keras orang memukul, menendang, seberapa jauh melempar, seberapa tinggi melompat, seberapa cepat berlari dan sebagainya. Senada dari Jensen dalam Ballesteros (1993: 72) mengemukakan daya ledak adalah "semua gerakan explosif yang maksimal 
secara langsung tergantung pada daya”. Daya otot sangat penting untuk menampilkan prestasi yang tinggi.

Berdasarkan penjelasan pendapat para ahli di atas, maka dapat dikemukakan bahwa daya ledak adalah kemampuan mengarahkan kekuatan dalam waktu yang singkat untuk memberikan objek momentum yang paling baik pada tubuh atau objek dalam satu gerakan explosif yang utuh mencapai tujuan yang dikehendaki.

Menurut Syafruddin (2011: 158), kelentukan berbicara tentang kemampuan fungsi persendian/pergelangan seperti sendi bahu, lutut, kaki, pinggul, pergelangan tangan dan lain-lain. Kelentukan sangat menentukan keberhasilan seseorang pada setiap cabang olahraga pada umumnya, dan lompat tinggi gaya flop khususnya. Kelentukan merupakan salah satu komponen kondisi fisik yang tidak bisa dipisahkan dengan unsur kondisi fisik lainnya dalam melakukan suatu keterampilan gerak. Dalam melakukan keterampilan gerak pada setiap cabang olahraga pada umumnya dan pada lompat tinggi gaya flop khususnya.

Menurut Syafruddin (2011: 160), pada dasarnya kelentukan dapat dilihat dari beberapa sudut pandang. Bila dilihat dari sudut kebutuhan suatu cabang olahraga, maka kelentukan dapat dibedakan atas kelentukan umum dan kelentukan khusus. Sedangkan bila dilihat dari bentuk pelaksanaannya maka kelentukan dapat dikelompokkan atas kelentukan aktif dan kelentukan pasif serta kelentukan statis dan dinamis. Maka, semakin bagus kelentukan seseorang khususnya mahasiswa yang akan melakukan lompat tinggi maka akan semakin mudah dalam melakukan berbagai macam gerakan terutama saat melakukan gaya flop dalam seperti saat melakukan fase utama, fase awal dan fase akhir.

Gerakan awalan berfungsi untuk memperoleh kecepatan gerakan, dan menunjang tubuh pada saat menolak. Kecepatan gerak tubuh saat awalan, berupa kecepatan gerak di bidang horizontal, yang kemudian diubah menjadi kecepatan dibidang vertical. Dalam lompat tinggi gaya flop, untuk memperoleh lompatan 
yang paling tinggi, maka kaki yang lebih kuat harus digunakan untuk melakukan tolakan (tumpuan). Pelompat yang menggunakan gaya flop, maka kaki tolak harus berada di bagian luar, sedangkan kaki bebas (kaki ayun) berada di antara matras dan kaki tolak.

Ketika pelompat tinggi melayang di udara, maka posisi tubuh sudah tidak dapat diubah lagi, karena seluruh bagian anggota badan tidak berhubungan lagi dengan bidang tumpu. Lintasan gerakan tubuh ketika melayang di atas mistar, sangat ditentukan oleh pengambilan awalan dan tolakan

\section{B. METODOLOGI PENELITIAN}

Penelitian ini bertujuan untuk menjelaskan besarnya kontribusi antara daya ledak otot tungkai, dan kelentukan baik secara sendiri-sendiri, maupun bersama-sama terhadap hasil lompat tinggi gaya flop. Penelitian ini tergolong pada jenis penelitian kuantitatif yang menggunakan teknik regresi dan korelasi baik tunggal maupun ganda. Umar (1998: 15) menguraikan bahwa korelasional adalah suatu penelitian yang dirancang untuk menentukan tingkat hubungan variable-variabel yang berbeda dalam suatu populasi dan bertujuan untuk mengetahui berapa besar hubungan variable bebas terhadap variable terikat melalui koefesien determinasi. Adapun variabel yang dihubungkan dalam penelitian ini adalah daya ledak otot tungkai $\left(\mathrm{X}_{1}\right)$, dan kelentukan pinggang $\left(\mathrm{X}_{2}\right)$, sedangkan variabel terikatnya yaitu hasil lompat tinggi gaya flop (Y).

Menurut Sugiyono (2010:61), "populasi adalah wilayah generalisasi yang terdiri atas: obyek/subyek yang mempunyai kualitas dan karakteristik tertentu yang ditetapkan oleh peneliti untuk dipelajari dan kemudian di tarik kesimpulannya". Populasi dalam penelitian ini adalah seluruh mahasiswa Program studi pendidikan olahraga yang mengambil perkuliahan atletik 3 yang sudah diajarkan materi lompat tinggi pada atletik 2, khususnya lompat tinggi dengan menggunakan gaya flop, berjumlah 254 orang dengan sebaran 240 orang mahasiswa putra dan 14 orang mahasiswa putri. 
Pengambilan sampel pada penelitian ini dilakukan dengan teknik purposive sampling. Menurut Margono (2003:128), purposive sampling adalah" pemilihan sekelompok subjek yang didasarkan atas ciri-ciri tertentu yang diterapkan berdasarkan tujuan penelitian”. Jumlah sampel penelitian ini adalah 37 orang. Sampel yang digunakan bersifat Homogen karena hanya mahasiswa laki-laki saja sebagai objek yang diteliti.

Untuk mengukur daya ledak otot tungkai dari testee digunakan vertical power jump test, kelentukan pinggang dengan melakukan Bridge-up (kayang) dan hasil lompat tinggi menggunakan tes lompat tinggi dengan gaya flop sesuai dengan peraturan PASI sebanyak tiga kali pengulangan. Data yang diambil adalah lompat tertinggi dengan menggunakan gaya flop.

Teknik analisa data yang digunakan adalah teknik analisis regresi, korelasi sederhana dan ganda. Hipotesis 1 dan 2 di analisis dengan regresi dan korelasi sederhana, sedangkan hipotesis 3 di analisis dengan korelasi ganda. Sebelum melakukan analisis terhadap data di atas, dilakukan uji persyaratan Uji normalitas, Uji linearitas, dan Uji independen variabel bebas.

\section{HASIL PENELITIAN DAN PEMBAHASAN}

Pengolahan data penelitian disajikan secara berurutan dapat dilihat pada tabel sebagai berikut.

Tabel 1. Rata Hitung dan Standar Deviasi Data Penelitian

\begin{tabular}{lccccc}
\hline \multicolumn{1}{c}{ Variabel } & $\mathrm{N}$ & $\overline{\mathrm{X}}$ & Std.dev & Min & Max \\
\hline Daya ledak otot tungkai & 37 & 96.88 & 10.15 & 72.75 & 118.65 \\
Kelentukan pinggang & 37 & 43.76 & 12.24 & 19 & 63 \\
Hasil lompat tinggi gaya flop & 37 & 128.41 & 18.60 & 100 & 162 \\
\hline
\end{tabular}

Uji normalitas variabel menggunakan uji Lilliefors menunjukkan bahwa data berasal dari populasi yang berdistribusi normal. Hasil lengkap uji Liliefors dapat dilihat pada tabel sebagai berikut. 
Tabel 2. Uji Normalitas Variabel

\begin{tabular}{lcccc}
\hline \multicolumn{1}{c}{ Variabel } & $\mathbf{N}$ & $\mathbf{L}_{\mathbf{0}}$ & $\mathbf{L}_{\text {tabel }}$ & Ket \\
\hline Daya ledak otot tungkai & 37 & 0.1332 & 0.146 & Normal \\
Kelentukan pinggang & 37 & 0.1026 & 0.146 & Normal \\
Hasil lompat tinggi gaya flop & 37 & 0.0885 & 0.146 & Normal \\
\hline
\end{tabular}

Uji linearitas adalah uji yang dilakukan untuk melihat apakah masingmasing data variabel daya ledak otot tungkai, dan kelentukan pinggang cenderung membentuk garis linear terhadap variabel hasil lompat tinggi gaya flop. $\mathrm{H}_{\mathrm{o}}$ yang di uji dalam hal ini adalah data daya ledak otot tungkai $\left(\mathrm{X}_{1}\right)$, dan kelentukan pinggang $\left(\mathrm{X}_{2}\right)$, memiliki hubungan yang linear dengan hasil lompat tinggi gaya flop $(\mathrm{Y})$. Kriteria pengujian adalah terima $\mathrm{H}_{\mathrm{o}}$ jika nilai $\mathrm{f}_{\text {hitung }}$ yang diperoleh dari perhitungan $<\mathrm{f}_{\text {tabel. }}$. Rangkuman hasil uji linearitas dapat dilihat dibawah ini.

Tabel 3. Rangkuman uji lineritas variabel daya ledak otot tungkai $\left(X_{1}\right)$, dan kelentukan pinggang $\left(\mathrm{X}_{2}\right)$ terhadap hasil lompat tinggi gaya flop $\mathrm{Y}$

\begin{tabular}{cccc}
\hline Variabel & $\mathrm{f}_{\text {hitung }}$ & $\mathrm{f}_{\text {tabel }} \alpha=0,05$ & Kesimpulan \\
\hline $\mathrm{X}_{1}-\mathrm{Y}$ & 0,90 & 2,72 & Linear \\
$\mathrm{X}_{2}-\mathrm{Y}$ & 0,57 & 2,33 & Linear \\
\hline
\end{tabular}

Hasil analisis pertama menunjukkan bahwa daya ledak otot tungkai $\left(\mathrm{X}_{1}\right)$ memiliki hubungan yang signifikan serta memberikan kontribusi yang berarti terhadap hasil lompat tinggi gaya flop. Nilai persamaan regresi dapat digambarkan sebagai berikut $\hat{\mathrm{Y}}=52.74+0.79 \times$ dengan $\mathrm{f}_{\text {hitung }} 1,57<\mathrm{f}_{\text {tabel }} 2.74$.

Tabel 4. Daftar ANAVA Regresi Linear $\hat{Y}=52.74+0.79 x$

\begin{tabular}{ccccccc}
\hline Sumber Variasi & Dk & JK & KT & Fh & Fta $=0,05$ & Kesimpulan \\
\hline Total & 36 & 614772 & - & - & & \\
Koefisien (a) & 1 & 601658.78 & - & & & Regresi \\
Regresi (b/a) & 1 & 2280.63 & 2280.63 & $7.16^{*}$ & 4.12 & $\begin{array}{c}\text { Signifikan } \\
\text { (berarti) }\end{array}$ \\
Sisa & 34 & 10832.60 & 318.61 & & & Regresi \\
Tuna Cocok & 24 & 8557.68 & 356.57 & & & Linear \\
Galat & 10 & 2274.92 & 227.49 & & 2.74 & \\
\hline
\end{tabular}


Hasil analisis kedua menunjukkan bahwa kelentukan pinggang $\left(\mathrm{X}_{2}\right)$ memiliki hubungan yang signifikan serta memberikan kontribusi yang berarti terhadap hasil lompat tinggi gaya flop. Nilai persamaan regresi dapat digambarkan sebagai berikut $\hat{Y}=104,37+0,56 \times$ dengan $F_{\text {hitung }} 0,64<\mathrm{f}_{\text {tabel }} 2,48$.

Tabel 5. Daftar ANAVA Regresi Linear $\hat{\mathbf{Y}}=\mathbf{1 0 4 , 3 7 + 0 , 5 6} \mathrm{x}$

\begin{tabular}{|c|c|c|c|c|c|c|}
\hline Sumber Variasi & $\mathrm{Dk}$ & $\mathrm{JK}$ & KT & Fh & $\mathrm{Ft} \alpha=0,05$ & Kesimpulan \\
\hline Total & 36 & 614772 & - & 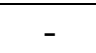 & & \\
\hline Koefisien (a) & 1 & 601658.78 & - & & & Regresi \\
\hline Regresi (b/a) & 1 & 1635.59 & 1635.59 & 4.84 & 4.12 & Signifikan \\
\hline Sisa & 34 & 11477.63 & 337.58 & & & (berarti) \\
\hline Tuna Cocok & 20 & 5503.85 & 275.19 & 0.64 & 2.48 & Regresi \\
\hline Galat & 14 & 5973.78 & 426.70 & 0.04 & 2.48 & Linear \\
\hline
\end{tabular}

Selanjutnya diperoleh koofisien determinasi melalui koofisien korelasi dikuadratkan dari riap tiap analisis data. Adapun rnagkuman hasil kefisien korelasi dapat dilihat pada tannel berikut:

Tabel 6. Uji Rangkuman Uji Signifikansi Korelasi

\begin{tabular}{cccccc}
\hline $\begin{array}{c}\text { Korelasi } \\
\text { Antara }\end{array}$ & $\begin{array}{c}\text { Koefisien } \\
\text { Korelasi }\end{array}$ & $\begin{array}{c}\text { Koefisien } \\
\text { Determinasi }\end{array}$ & $\mathrm{T}_{\text {hitung }} / \mathrm{F}_{\text {hitung }}$ & $\begin{array}{c}\mathrm{T}_{\text {tabel }} / \\
\mathrm{F}_{\text {tabel }}\end{array}$ & Kesimpulan \\
\hline $\mathrm{X}_{1}$ dengan Y & 0,45 & $20.25 \%$ & 2,977 & 1.691 & Signifikan \\
$\mathrm{X}_{2}$ dengan Y & 0,34 & $11.56 \%$ & 2,121 & 1,691 & Signifikan \\
$\mathrm{X}_{1} \mathrm{X}_{2}$ dengan & 0,51 & $26.01 \%$ & 6.89 & 3.28 & Signifikan \\
Y & & & & & \\
\hline
\end{tabular}

Selanjutnya, analisis kedua variabel $\left(\mathrm{X}_{1}\right.$ dan $\left.\mathrm{X}_{2}\right)$ menunjukkan bahwa variabel daya ledak otot tungkai dan variabel kelentukan pinggang secara bersama-sama memiliki hubungan yang signifikan serta memberikan kontribusi yang berarti terhadap hasil lompat tinggi gaya flop. Pada tabel korelasi analisis diperoleh koofesien korelasi variabel daya ledak otot tungkai dan kelentukan pinggang terhadap hasil lompat tinggi gaya flop dengan harga koofisien regresi $\hat{Y}$ $=42,64+0,69 X_{1}+0,45 X_{2}$. 
Tabel 7. Anava pengujian Signifikansi Regresi Ganda

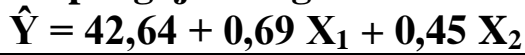

\begin{tabular}{cccccc}
\hline Sumber varians & DK & JK & RJK & F $_{\text {hitung }}$ & $F_{\text {tabel }}$ \\
\hline Regresi & 3 & 3192.87 & 1596.43 & 6.89 & 3.28 \\
Sisa & 26 & 9266.05 & 341.95 & & \\
\hline Dereduksi & 30 & & & & \\
\hline
\end{tabular}

Dari hasil penelitian tersebut maka dapat dijelaskan bahwa Daya ledak otot tungkai merupakan komponen utama yang paling menunjang terhadap hasil lompat tinggi gaya flop. Setelah memahami bentuk gaya flop, dapat kita ketahui ada beberapa faktor komponen kondisi fisik yang memiliki kontribusi dalam melakukan teknik gaya flop yaitu, daya ledak otot tungkai yang berfungsi untuk memberikan kekuatan dalam mendorong tubuh ke atas dan kecepatan kaki dalam melakukan tolakan ke atas.

Pada saat melakukan lompat tinggi gaya flop sangat dibutuhkan kekuatan kaki serta kecepatan pada saat melakukan awalan dan tolakan, maka otot-otot tungkai bagian bawah harus bisa memompakan tenaga lebih besar. Sebaliknya apabila mahasiswa memiliki daya ledak yang kurang bagus maka mahasiswa tersebut akan mengalami kesulitan melakukan awalan dan tolakan, sehingga hasil lompat tinggi gaya flop yang dihasilkan kurang baik. Hal ini karena kekuatan dan kecepatan untuk mendorong tubuh ke atas tidak dimiliki oleh mahasiswa tersebut.

Kelentukan pinggang merupakan salah satu variabel yang menunjang hasil lompat tinggi gaya flop. Kelentukan membantu tubuh untuk melakukan lentingan pada saat berada di atas mistar sehingga tubuh bagian belakang dapat mengurangi gesekan terhadap mistar. Oleh karena itu kelentukan juga memiliki peranan penting terhadap hasil lompat tinggi gaya flop.

Dalam keseluruhan kegiatan fisik, peranan kelentukan sangatlah penting terutama pada cabang-cabang olahraga yang banyak menggunakan gerak sendi. Apabila kelentukan yang dimiliki bagus, maka akan membantu tubuh untuk 
melakukan lentingan pada saat berada di atas mistar sehingga tubuh bagian belakang dapat mengurangi gesekan terhadap mistar.

Untuk mendapatkan lentingan yang bagus di atas mistar dibutuhkan kelentukan pinggang yang bagus. Penggabungan gerakan ini hanya dapat dilakukan dengan baik apabila ditunjang oleh kondisi fisik yang baik. Berdasarkan penjelasan inilah diduga bahwa daya ledak otot tungkai dan kelentukan pinggang secara bersama-sama berkontribusi terhadap hasil lompat tinggi gaya flop.

\section{SIMPULAN}

Berdasarkan pada hasil analisis data dan pembahasan yang dijabarkan dapat diambil kesimpulan sebagai berikut.

1. Daya ledak otot tungkai berkontribusi signifikan terhadap hasil lompat tinggi gaya flop, dengan kontribusi sebesar $20.25 \%$.

2. Kelentukan pinggang berkontribusi signifikan terhadap hasil lompat tinggi gaya flop, dengan kontribusi sebesar $11.56 \%$.

3. Daya ledak otot tungkai dan kelentukan pinggang secara bersama-sama berkontribusi signifikan terhadap hasil lompat tinggi gaya flop, dengan kontribusi sebesar $26.01 \%$.

\section{DAFTAR PUSTAKA}

Ballesteros, Jose Manuel. 1993. Pedoman Dasar Melatih Atletik. Jakarta: Program Pendidikan \& Sistem Sertifikasi Pelatih Atletik. Persatuan Atletik Seluruh Indonesia.

Bompa, O Tudor. 2006. Total Training for Young Champions. York University: Human Kinetics.

Harsono. 2006. Coaching dan Aspek-aspek Psikologis dalam Coaching. Jakarta: Depdikbud Dirjen Dikti P2LPTK.

Margono. 2003. Metodologi Penelitian Pendidikan. Jakarta: Rineka Cipta. 
Sugiyono. 2010. Statistika untuk Penelitian. Bandung: Alfabetha

Syafruddin. 2011. Dasar-Dasar Kepelatihan Olahraga. Padang: Sukabina Press.

Syarifuddin, AIP. 1998. Pendidikan Jasmani dan Kesehatan. Jakarta: Departemen P\&K Direktorat Jendral Pendidikan Tinggi Proyek Pembinaan Tenaga Kependidikan.

Umar, Husen. 1998. Metode Penelitian untuk Skripsi dan Tesis Bisnis. Jakarta: Rajagrafindo Persada.

UURI/No III/. 2005. Sistem Keolahragaan Nasional. Yogyakarta: Pustaka Yustisia.

Winarno, M.E. 2006. Perspekstif Pendidikan Jasmani dan Olahraga. Malang: Laboratorium Jurusan Ilmu Keolahragaan Fakultas Ilmu Pendidikan Universitas Negeri Malang. 